\title{
УДК 372.881 .1 \\ ВИКОРИСТАННЯ ДІЛОВИХ ІГОР ДЛЯ НАВЧАННЯ МАЙБУТНІХ ЕКОНОМІСТІВ АНГЛОМОВНОГО ДІАЛОГІЧНОГО МОВЛЕННЯ
}

\author{
Зайцева I. B. \\ Irenenazaruk8@gmail.com \\ Київський національний торговельно-економічний університет \\ Дата надходження 05.09.2018. Рекомендовано до друку 15.10.2018.
}

\begin{abstract}
У статті досліджується використання ділових ігор для навчання майбутніх економістів діалогічного мовлення; розкрито зміст поняття “ділова гра”. Проаналізовано наявні наукові концепції щодо навчання ділової англомовної діалогічної мови й ділової гри. Обгрунтовано ефективність і необхідність використання ділових ігор для навчання майбутніх економістів діалогічного мовлення. Визначено й описано типи ділових ігор, принципи навчання ділової англомовної діалогічної мови. Виділено та описано етапи навчання ділової гри, наведено приклади вправ.
\end{abstract}

Ключові слова: ділова гра, майбутні економісти, діалогічне мовлення, підготовка до професійного спілкування.

Зайцева И. В. Использование деловых игр для обучения будущих экономистов диалогической речи. В статье исследуется использование деловых игр для обучения будущих экономистов диалогической речи; раскрыто содержание понятия “деловая игра”. Проанализированы существующие научные концепции относительно обучения деловой английской диалогической речи и деловой игры. Обоснована эффективность и необходимость использования деловых игр для обучения будущих экономистов диалогической речи. Определены и описаны типы деловых игр, принципы обучения деловой английской диалогической речи, выделены и описаны этапы обучения деловой игры, приведены примеры упражнений.

Ключевые слова: деловая игра, будущие экономисты, диалогическая речь, подготовка к профессиональному общению.

Zaitseva I. V. Kyiv National University of Trade and Economics

Using Business role play for teaching prospective economists interaction in English.

Abstract. Introduction. The article deals with the use of business role play for teaching prospective economists interaction in English. The author finds out of essence of the concept «business role play». The emphasis is placed on the use of business role plays for teaching students majoring in Economics professional interaction. The study singles out the business role play's characteristics and peculiarities. The author analyses types of business role play. The purpose of this article is to single out business role play usage for teaching prospective economists interaction in English. Within the context of this research, we have formed a hypothesis that it is possible to develop the English-speaking interactional competence of the prospective economists by the means of business role play. Methods. The studies on methods of teaching prospective economists interaction in English conducted abroad and in Ukraine have been reviewed and the typology of business role plays have been considered. The results. The author defines the notion of a business role play and finds the differences with a role play. The typology of business role plays and tasks for teaching first-year students interaction in English have been developed. The stages for teaching prospective economists interaction in English have been suggested and described. The examples of the exercises have been given. Conclusion. To sum up, critical structural features of a business role play are analysed in the research. The peculiarities of a business role play are the theme; the problematic situation; roles; co-speakers; the aim; the instruction. The importance of the business role play usage is listed in the study. The types and key stages of a business role play are described. Language skills of prospective economists are developed at every stage of a business role play.

Key words: business game, future economists, dialogical speech, preparation to professional interaction.

Постановка проблеми. На сучасному етапі здійснення міжкультурної комунікації, розширення міжнародного співробітництва в різних сферах діяльності, створення спільних підприємств володіння англійською мовою стає необхідністю. Згідно з положеннями стандарту підготовки студентів економічних спеціальностей, Загальноєвропейських рекомендацій з мовної освіти, 
а також Національної доктрини розвитку освіти в Україні у XXI столітті володіння англійською мовою професійного спрямування має першочергове значення (Ніколаєва, 2003; Бігич та ін., 2013; Президент України, 2002). Сучасні ринкові відносини зумовлюють жорсткі вимоги до якості та рівня професійної підготовки студентів-економістів, які спроможні генерувати ідеї розвитку підприємства, виявляти можливі напрямки його розвитку, вести професійний діалог $з$ представниками бізнес-середовища. Тому виникає необхідність навчання майбутніх економістів англійського діалогічного мовлення професійного спілкування (Н. Ф. Бориско, В. Д. Борщовецька, Н. В. Зінукова, С. С. Коломієць, З. М. Корнєва, М. Ф. Стронин, О. Б. Тарнопольський, Л. А. Чубарова та ін.).

Отже, одним із першочергових завдань освіти стає якісна підготовка спеціалістів, які здатні до успішної професійної діяльності в межах світової спільноти. Досягнення цього завдання ми вбачаємо у навчання майбутніх економістів діалогічного мовлення професійного спрямування для спеціальних цілей у навчальному процесі. При цьому необхідно навчати норм міжкультурного спілкування; розвивати культуру мовлення; моделювати проблемні ситуацій, в яких студенти можуть опинитися в реальному житті, (Галькова и Гез, 2004; Рогова, 1974; Соловова, 2002). Одним із способів організації навчання діалогічного мовлення (ДМ) майбутніх економістів методисти вважають застосування ділових ігор.

Аналіз останніх досліджень і публікацій. Проблема використання ділових ігор для навчання майбутніх економістів діалогічного мовлення - не нова, але завжди була актуальною, оскільки вона перебуває у центрі уваги методистів і вчених. Питаннями обгрунтування доцільності та перспективності використання ділових ігор у вищій школі займалися такі дослідники, як Л. Г. Вишнякова, Ю. А. Гапон, Т. І. Доніч, А. В. Конишева, Л. Б. Котлярова, Н. Н. Круглова, О. Б. Тарнопольський, В. М. Філатов, А. Davison, P. Gordon та інші).

Аналіз наукових джерел свідчить, що за останні роки інтенсивно вивчалися окремі аспекти навчання ділової англійської мови (ДАМ) - Business English, зокрема розроблена методика навчання студентів-економістів ДАМ за методикою "занурення" (“immersion teaching"), що передбачає навчання в значущих ситуаціях спілкування через викладання однієї чи кількох навчальних дисциплін іноземною мовою (3. М. Корнєва). Обгрунтовано методику навчання майбутніх економістів ділового писемного мовлення (Н. Л. Драб, Т. М. Корж, Г. С. Скуратівська), зокрема, з використанням електронних засобів та інформаційно-комунікативних технологій (О. П. Биконя, М. М. Метьолкіна). Запропоновано методику навчання студентів-економістів англійської мови професійного спілкування з використанням бізнес-проектів (Ю.В.Дегтярьова), бізнес-гри (О. Б. Тарнопольський, С. П. Кожушко), а також мовного портфеля (Н. В. Ягельська). Як бачимо, проблема навчання майбутніх економістів ДАМ досить докладно досліджена вченими, однак процес використання ділових ігор для навчання майбутніх економістів ДМ висвітлений недостатньо.

Проте методика навчання майбутніх економістів діалогічного мовлення з використанням ділових ігор висвітлена недостатньо. До того ж, невідповідність між вимогами до професійної підготовки фахівця економічного профілю й наявним рівнем сформованості компетентності в ДМ зумовили необхідність дослідження проблеми підготовки майбутніх економістів до професійного спілкування.

Таким чином, метою статті $є$ обгрунтування використання ділових ігор для навчання майбутніх економістів діалогічного мовлення. Реалізація зазначеної вище мети передбачає вирішення таких завдань: уточнити визначення поняття “ділова гра", виділити й описати принципи навчання ДМ для майбутніх економістів, проаналізувати переваги використання ділової гри для навчання ДМ, визначити етапи навчання майбутніх економістів ділової гри.

Основні результати дослідження. Розглянемо, як трактують поняття “ділова гра” науковці сьогодні. На думку М. Ф. Строніна, гра у навчальному процесі передбачає наявність ситуації, 
максимально наближеної до реальних умов спілкування з властивими йому ознаками: емоційністю, спонтанністю, цілеспрямованістю мовного впливу (Стронин, 1981, с. 77). Поряд 3 назвою “ділова гра”, яка є “імітацією трудової діяльності, а також окремих сторін життя" (Эльконин, 1978), розглядається як “імітація майбутньої професійної діяльності” (Щербань, 2004, с. 20). У свою чергу П. М Щербань (2004) визначає поняття “організаційно-ділові ігри, пов'язані з керівництвом навчально-виховним процесом".

Таким чином, враховуючи мету нашого дослідження, ми розглядаємо ділову гру як інтерактивний метод навчання майбутніх економістів діалогічного мовлення у групах або парах, моделювання реального професійного спілкування, що стимулює пізнавальну активність студентів. Серед ознак, що властиві діловій грі, найважливішими є: наявність проблемної ситуації, ролей, емоційність, спонтанність, цілеспрямованість.

Загальна мета навчальних ділових ігор - активізація процесу навчання та прискорення формування у студентів комплексу знань, навичок і вмінь, необхідних для підвищення ефективності діяльності спеціалістів. Так, у процесі ділової гри у майбутніх економістів формуються фонетичні, лексичні, граматичні навички, студенти набувають досвіду мовного спілкування (Щербань, 2004; Eitington, 2001; Livingstone, 1988). Ділові ігри під час навчального процесу доцільно використовувати для зняття мовних труднощів, у процесі відпрацювання мовного матеріалу, активізації мовної діяльності. Як засіб імітації професійної діяльності, ділові ігри інтенсифікують процес навчання. Серед переваг використання ділової гри для навчання ДМ - розв'язання проблемної ситуації (ПС), під час якої відбувається максимальна активізація комунікативної діяльності студентів. До того ж, під час ділової гри, яка забезпечує моделювання умов професійної діяльності майбутніх економістів, створюються умови для застосування професійних знань, удосконалення мовленнєвих навичок та розвиток дискусійних умінь, пошук варіантів вирішення завдання, розвиток уміння аргументувати власну думку, переконувати, впливати на учасників гри тощо.

Зазначимо, що ділова гра відрізняється від рольової гри за певними критеріями: орієнтація на майбутню професію студентів, моделювання у грі умов професійної діяльності, наближених до реальних.

Розкриття поняття “ділова гра” дає нам можливість перейти до іï структури, а саме до визначення етапів ділової гри, під час яких виконання завдань попереднього етапу має вплив на результат виконання завдань у наступному етапі, на контроль ігрового часу та систему оцінки іiі результатів (Щербань, 2004, с. 131). Створення ситуації передбачає наявність проблемного завдання, а також підготовку номенклатури ролей: You're a sales person working for Fast Cars showroom. Look at the following facts below and negotiate a deal with a potential buyer. Use some of the expressions in the box below.

- You have to sell the new Suzuki model. You need to earn a minimum commission of 1000 in the next few days in order to pay for your trip to Poland. This is your bottom line but you could use more money, as the holiday is expensive.

- You make only 50 for cars sold under 10 000. You make a commission per car sold between 10000 and 12000 . You make 150 commission for cars sold over 12000.

- This is the second time the buyer has visited the showroom. If the buyer's first offer is lower than you'd like, persuade him/her to buy a more expensive model with special features.

To take it to leave it willing to make concession you are giving one some sort of compensation walk away from the negotiation one by one understand the value ill-will big concession 
Sales negotiations: tips for making concessions:

1. Don't do

2. Don't think you have to match your customer's concessions.

3. Never give away a concession from a client when.....

4. The best time to get a concession from a client when

5. Whatever you do, don't advertise you're.

6. Make it clear that the .............offer is unacceptable. When facing this situation, restate your position and its benefits to the customer. Never use these words yourself. They only create anger and......

7. If the customer is not planning to buy, it's sensless negotiating and you need to

Під час ділової гри студент може діяти в межах ПС, виконуючи роль відповідно до ситуації. Перевагами рольових ігор також є такі важливі якості, як максимальне наближення до реального життя, автономність студентів, прийняття спонтанних рішень та знаходження компромісу (Эльконин, 1978, с. 193). Використання ділової гри під час занять з АМ сприяе розвитку уяви та умінь критичного мислення, формуванню здатності знаходити й розглядати альтернативні можливості, виокремити власну думку щодо ситуації.

До того ж, ділова гра передбачає наявність різних моделей спілкування, які становлять систему професійного спілкування майбутнього фахівця: наявність ролей та їх розподіл між учасниками; взаємодія; наявність спільної мети в учасників ділової гри тощо. Відтак, можна сказати, що у ділових іграх завжди $є$ наявність ПС, яка розглядається як створення певних умов, що містять проблему, яку необхідно вирішити (Чубарова, 2003, с. 23).

Ділові ігри поділяють на (Гайденко, 2016, с. 20):

1) гру-співробітництво (ведення переговорів між представниками компаній/ споживачами/ клієнтами/ колегами з метою досягнення домовленості або пошуку варіантів вирішення проблеми). Наведемо приклад такого виду ділової гри.

\section{Role card 1}

You are a junior member of a sales team and want to go on a conference negotiating techniques in Paris in Aprils for being precise. Negotiate the trip with your boss and justify the expense. Remember to ask specific questions and use expressions for being precise.

$$
\text { Role card } 2
$$

You are a sales manager. A junior but enthusiastic member of your sales team makes a request. Be vague about whether you agree to or decline the request unless you're asked specific questions. Your final decision depends on his/her arguments.

2) Гру-змагання (наприклад, підготовка та представлення проектів фірмами-конкурентами з метою отримання патентів на виготовлення продукціï): ділова гра “ Who to Promote?”. Work in groups of three.

\begin{tabular}{|l|l|l|}
\hline \multicolumn{1}{|c|}{ Role card 1 Nick } & \multicolumn{1}{c|}{ Role card 2 Alice } & \multicolumn{1}{c|}{ Role card 3 Steve } \\
\hline You have a small business. & Alice is very hard-working. & Steve is has leadership \\
Your business is successful. & She is a good speaker and has & abilities. Everyone respects \\
You would like to promote & got experience in the company & and trusts him. He seldom \\
one of your two employees & for five years. Her disadvantage & makes mistakes in his work. \\
Alice or Steve. Whom will & is that she can be stubborn. & His weak points are that he is \\
you choose and why? & & $\begin{array}{l}\text { a slow worker and he can } \\
\text { come to work late. }\end{array}$ \\
\hline
\end{tabular}

Suggested expressions: "Both candidates have advantages and disadvantages." "Alice is more serious and experienced." "Steve is more skillful." "If we choose Alice,..". 
3) Гру-конфлікт (наприклад, непорозуміння між колегами, переговори керівництва підприємства 3 представниками іноземної фірми стосовно зриву постачань продукції тощо): Your co-worker often asks you to 'cover'for him. For example, yesterday he took an extra half-hour for lunch and he asked you to tell the boss that he was in a meeting. Use the suggested phrases innyour speech.

Student A: Your colleague wants you to cover for him again. You are bored because of his behaviour and you are worried that the executive will get to know the truth.

Student B: You need to take some time on your lunch break to buy some medicine for your son from the pharmacy. Ask your colleague to cover for you.

Suggested phrases:

"He can catch us..."

"The executive is suspicious."

"Please, do me a favour."

"This is urgent."

Кожен тип гри відрізняється специфікацією цілей, на досягнення яких спрямовані зусилля iii учасників.

Для більш ефективного використання потенціалу ділових ігор у навчанні ДМ визначимо передумови, що надають можливість досягти високих результатів. Нагадаємо, що будь-яка навчальна система базується на загальнодидактичних принципах. Під принципами навчання ми розуміємо слідом за Г.В. Роговою $(1974$, с. 85$)$ положення, які визначають організацію навчання, зміст, методи і є взаємопов'язаними і взаємообумовленими. Принципи навчання ДАМ, а саме професійного спілкування розглядалися у багатьох наукових працях. Найбільш вагомою для нашого дослідження виявилася класифікація принципів А. І. Кузьмінського (2005, сс. 222-228): науковості, систематичності та послідовності, наочності, зв'язку навчання з професійною діяльністю, випереджальної професійної спрямованості змісту навчального матеріалу, новизни, оптимізаиії деталей гри. Розглянемо їх докладніше.

1. Принцип науковості передбачає засвоєння майбутніми економістами наукових положень, що знайомлять їх із основами економіки, системою економічних категорій, законами ринкового господарства тощо. Його реалізація відображається у навчальних програмах, підручниках, посібниках із кожної дисципліни.

2. Принцип систематичності та послідовності означає, що розгляд навчального матеріалу відбувається поступово і послідовно, із встановленням логічних зв'язків між темами.

3. Принцип наочності - один з провідних дидактичних принципів, згідно з яким навчання побудоване на образах. $Є$ два шляхи реалізації принципу наочності на заняттях з IM: використання наочності як засобу навчання і засобу пізнання. У першому випадку - це спеціально дібрані зорові та слухові наочні матеріали (звукозапис, таблиці, схеми, ситуативні картинки, інтелектуальні карти, штучні та природні опори і складніші для сприйняття зразки наочності - відеосюжети телепередач), що допомагають студентам оволодіти нормами вимови, лексико-граматичними одиницями, навчитися розуміти мовлення та висловлювати свою думку у межах відібраного кола тем і ситуацій спілкування. У другому випадку засоби наочності є джерелом інформації, наприклад, інформація про країну, мова якої вивчається, або майбутньої професії студента.

4. Принцип зв'язку навчання з професійною діяльністю передбачає практичну апробацію теоретичних знань, що дає змогу розвивати вміння ДМ та формувати навички. Для реалізації цього принципу необхідно не лише використання ділових ігор на заняттях з АM, а також участь у виробничій практиці на підприємствах різних галузей.

5. Принцип випереджальної професійної спрямованості змісту навчального матеріалу спрямований на вирішення завдань спілкування, пов'язаних з майбутньою професійною діяльністю студента, під якою ми розуміємо професійно-трудову сферу, пов'язану з організацією 
та розвитком виробництва, а також рекламою, продажем, купівлею товарів та послуг. Цей принцип зумовлює включення в навчання ситуацій і тем усного професійного спілкування, наприклад “Майбутня професія", “Працевлаштування”, а також передбачає моделювання у навчальному процесі ситуацій професійного спілкування в умовах виконання певних соціальних ролей: менеджера, аудитора, бухгалтера, керівника компанії, у ході бесіди із зарубіжними колегами під час переговорів тощо.

6. Принцип новизни передбачає такі критерії:

- новизна умов для розвитку мовленнєвих вмінь, а саме: постійна зміна завдань, тощо; новизна змісту має бути на такому рівні, щоб студенти відчули необхідність обговорити проблему;

-новизна прийомів і видів роботи, новизна організаційних форм. Правильна реалізація цього принципу забезпечує спілкування вже на початковому етапі, що є важливою передумовою формування компетентності в говорінні, зокрема у ДМ.

7. Принцип оптимізації деталей гри. Ділова навчальна гра повинна максимально наближатись до реальних умов майбутньої професійної діяльності фахівця. Але при цьому необхідно стежити за тим, щоб ігрові ситуації були не обтяжені подробицями, які $є$ другорядними.

Виділивши й описавши основні принципи навчання ДМ майбутніх економістів, нам необхідно визначити етапи навчання ділової гри, від яких залежить їі результативність.

Перший етап - організаційно-мотиваційний - передбачає мотиваційну готовність студентів до обговорення ПС. Тому мета цього етапу - створення мотиваційної готовності до ДМ й організація останньої, передбачає вирішення таких завдань: відбувається підготовка до ділової гри, до початку якої необхідно підготувати сценарій, що містить номенклатуру ролей, інформацію про дії учасників гри, взаємовідносини між ними, опис місця й часу дій, визначає кінцеву мету гри. Це дає студентам змогу усвідомити завдання, знайти компроміс та реалізувати свої професійно-комунікативні та творчі можливості. На цьому етапі викладач опрацьовує зі студентами спеціально підготовлені матеріали професійного характеру. Цей процес може відбуватися на декількох заняттях, які передують тому заняттю, на якому проводитиметься сама гра. 3 метою підготовки студентів викладач може ознайомити їх зі зразком сценарію ділової гри, скласти з ними карту-схему послідовності ігрових дій, програти окремі фрагменти.

Другий етап - інформативно-підготовчий, який розпочинається із знайомства учасників ділової гри із ситуацією викладачем, розподілу ролей, залежно від умов гри: поділ на пари / групи / команди, забезпечення відповідними друкованими матеріалами тощо. Під час гри викладач може пасивно спостерігати, втручатися й надавати необхідну інформацію або навіть стати учасником гри, виконуючи одну з ролей. Це залежить від рівня комунікативної підготовки групи та досвіду студентів, які можуть грати вперше або раніше брали участь у такому виді навчальної діяльності. Наведемо приклад ділової гри, під час якої викладач пропонує студентам ПС та розподіляє ролі: You are going to speak about the problem with the sales team existing information-gathering system. Work in groups of three. Find the solution of the problem.

\begin{tabular}{|c|c|c|}
\hline $\begin{array}{l}\text { St. A is Robert, IT Manager at Cred } \\
\text { Company who faces the problems } \\
\text { concerning the sales team existing } \\
\text { information-gathering system. }\end{array}$ & $\begin{array}{l}\text { St. B is Kate, a successful } \\
\text { financial consultant. }\end{array}$ & $\begin{array}{l}\text { St. } C \text { is Bob, the } \\
\text { manager who is } \\
\text { responsible for many } \\
\text { projects. }\end{array}$ \\
\hline $\begin{array}{l}\text { Speak with Kate and Bob from Rin } \\
\text { Learning Alliance. You've worked with } \\
\text { their company before and know them. } \\
\text { Explain the problem with the sales team } \\
\text { existing information-gathering system } \\
\text { and your solution. Explain what you'd } \\
\text { like her company to do for. }\end{array}$ & $\begin{array}{l}\text { Listen to Robert. Explain } \\
\text { your point of view and try } \\
\text { to persuade him. Find the } \\
\text { possible ways of solving } \\
\text { the problem with Robert } \\
\text { and Bob. }\end{array}$ & $\begin{array}{l}\text { Listen to Robert. } \\
\text { Explain your point of } \\
\text { view and try to } \\
\text { persuade him. Find } \\
\text { the possible ways of } \\
\text { solving the problem } \\
\text { with Robert and Bob. }\end{array}$ \\
\hline
\end{tabular}


На третьому етапі - ситуативно-дискусійному, метою якого є проведення ділової гри, студенти, як правило, працюють разом, оскільки по черзі представляють в парах / групах позицію 3 проблемного питання, яке вони обговорювали. Умови гри визначають такі дії: завершити гру після презентації рішень чи продовжити іії з метою знайти спільне рішення тощо. Гра може також передбачати здійснення писемного спілкування, коли необхідно написати резюме, супроводжувальний лист, декларацію.

Останній етап - констатувально-інтерпретаційний - необхідний для формулювання висновків, підбиття підсумків і проведення аналізу ділової гри. Цей етап проводиться після завершення ділової гри і передбачає аналіз мовних, мовленнєвих помилок студентів, а також коментар з приводу їхньої рольової поведінки.

Наведемо приклад ділової ігри, під час якої майбутні економісти стануть виконавцями ролей, наприклад, роботодавця та найманого працівника. До того ж, студенти аналізують проведену гру, яку можна використовувати під час вивчення теми “Працевлаштування".

Simulation role play “Employment”. Учасники об’ єднуються у пари та по черзі розповідають один одному, що в їхньому житті, освіті, поведінці може ускладнювати пошук роботи. Наприклад: Brainstorm possible problems that an applicant could have: e.g. I have no / little job experience, I don't have higher education, I don't like the salary / the staff / the executive, I have a baby...

Завдання співрозмовників - знайти вихід із ситуації.

Така форма організації навчальної діяльності надає можливість студентам спробувати себе у певній ролі - керівника, президента компанії, дослідити систему роботи певного підприємства. Учасники гри вирішують професійно орієнтовані завдання - оптимізація прибутку фірми, укладення договорів, продаж акцій компанії тощо. Симуляції характеризуються високим ступенем зацікавленості учасників, котрі цілком поринають у гру, втілюються у свою роль. Симуляції впорядковують як фахові знання, так і знання іноземної мови студентів, готують останніх до прийняття у майбутній діяльності швидких та вмотивованих бізнес-рішень, сприяють формуванню навичок стратегічного мислення й планування, розвивають уміння працювати в команді тощо.

Таким чином, уточнено визначення поняття «ділова гра», розглянуто переваги ії використання для навчання майбутніх економістів ДМ, визначено принципи й етапи навчання ділової гри. Наведено приклади ділових ігор для навчання майбутніх економістів англомовного ДМ.

Перспективи подальших досліджень полягають у розробці технологій оволодіння майбутніми економістами стратегіями професійного спілкування.

\section{ЛIТЕРАТУРА}

Бігич, О. Б. Бориско, Н. Ф., Борецька, Г. Е., Голованчук Л. П., Ніколаєва С. Ю., Сажко Л. А., ... Черниш В. В. (2013). Методика навчання іноземних мов і культур : теорія і практика. Київ: Ленвіт.

Гальскова, Н. Д. и Гез, Н. И. (2004). Теория обучения иностранным языкам. Лингводидактика и методика. Москва: Академия.

Гайденко, Ю. О. (Уклад.). (2016). Методичні рекомендаџіï до організації та проведення ділових ігор на заняттях з іноземної мови у технічних університетах. Київ: НТУУ “КПІ".

Кміть, О. В. (2007). Ділова гра у навчанні професійно спрямованого англомовного спілкування студентів-міжнародників старших курсів. Вісник Чернігівського державного педагогічного університету. Серія: педагогічні науки, 48, 130-133.

Корнєва, 3. М. (2004). Навчання студентів економічного профілю вищих навчальних закладів України ділової англійської мови за методикою “занурення”. Іноземні мови, 4, 54-58.

Кузьмінський, А. І. (2005). Педагогіка вищцої школи. Киӥв: Знання.

Леонтьев, А. А. (1974). Психология общения. Тарту: Тартус. ГУ. 
Ніколаєва, С. Ю. (Наук. ред. укр. вид). (2003). Загальноєвропейські рекомендаиії з мовної освіти: вивчення, викладання, оцінювання. Київ: Ленвіт.

Тарнопольський, О. Б. (2003). Конспект лекцій з дисцииліни “Методика проведення рольових та ділових ігор у навчанні іноземних мов”. Дніпропетровськ: Видавництво ДУЕП.

Президент України. (2002). Указ “Про Національну доктрину розвитку суспільства” № 347 від 17 квітня 2002 року.

Рогова, Г. В. (1974). О принципах обучения иностранным языкам. Иностранные языки в школе, $6,85-95$.

Соловова, Е. Н. (2002). Методика обучения иностранным языкам : базовый курс лекиий. Москва: Просвещение.

Стронин, М. Ф. (1981). Обучающие игры на уроке английского языка (из опыта работы). Москва: Просвещение.

Тер-Минасова, С. Г. (2000). Язык и межкультурная коммуникаџия. Москва : Слово / Slovo.

Хухарева, Е. К. (2009). Роль деловой игры в обучении сотрудников современной кампании. Инноващии в образовании, 10, 85-96.

Чубарова, Л. А. (2003). Индивидуализаџия проблемных ситуаций в учебном процессе вуза (на материале изучения немецкого языка на языковом факультете) (Кандидатская диссертация). Тюменский государственный университет, Тюмень, Российская Федерация.

Щербань, П. М. (2004). Навчально-педагогічні ігри у вищих навчальних закладах. Київ: Вища школа.

Эльконин, Д. Б. (1978). Психология игры. Москва: Педагогика.

Яворська, Ж. (2005). Ділові ігри та їх роль у підготовці сучасних фахівців. Вісник Львівського Університету, 19, 241-246.

Eitington, J. E. (2001). The winning trainer : winning ways to involve people in learning. Oxford:

Butterworth-Heinemann.

Livingstone, C. (1988). Role Play in Language Learning. Москва: Высшая школа.

Philips, B. D. (1994). Role-playing games in the English as a Foreign Language Classroom. Crane Publishing Ltd.

Reeves, N. \& Wright, C. (1996). Linguistic auditing: a guide to identifying foreign language communication needs in corporations. Clevedon : Multilingual Matters.

Richards, J. C., Rodgers, T. S. (2001). Approaches and methods in language teaching. Cambridge: Cambridge University Press.

\section{REFERENCES}

Bihych, O. B. Borysko, N. F., Borets'ka, H. E., Holovanchuk L. P., Nikolaieva S. Yu., Sazhko L. A., ...Chernysh V. V. (2013). Metodyka navchannia inozemnykh mov i kul'tur : teoriia i praktyka. Kyiv: Lenvit.

Gal'skova, N. D. i Gez, N. I. (2004). Teorija obuchenija inostrannym jazykam. Lingvodidaktika i metodika. Moskva: Akademija.

Gajdenko, Ju. O. (Uklad.). (2016). Metodichni rekomendacii do organizacii ta provedennja dilovih igor na zanjattjah z inozemnoi movi u tehnichnih universitetah. Kiiv: NTUU "KPI".

Kmit', O. V. (2007). Dilova gra u navchanni profesijno sprjamovanogo anglomovnogo spilkuvannja studentiv-mizhnarodnikiv starshih kursiv. Visnik Chernigivs'kogo derzhavnogo pedagogichnogo universitetu. Serija: pedagogichni nauki, 48, 130-133.

Kornieva, Z. M. (2004). Navchannja studentiv ekonomichnogo profilju vishhih navchal'nih zakladiv Ukraini dilovoi anglijs'koi movi za metodikoju "zanurennja". Inozemni movi, 4, 54-58.

Kuz'mins'kij, A. I. (2005). Pedagogika vishhoi shkoli. Kiiv: Znannja.

Leont'ev, A. A. (1974). Psihologija obshhenija. Tartu: Tartus. GU. 
Nikolaieva, S. Yu. (Nauk. red. ukr. vyd). (2003). Zahal'noievropejs'ki rekomendatsii z movnoi osvity: vyvchennia, vykladannia, otsiniuvannia. Kyiv: Lenvit.

Tarnopol's'kyj, O. B. (2003). Konspekt lektsij z dystsypliny "Metodyka provedennia rol'ovykh ta dilovykh ihor u navchanni inozemnykh mov". Dnipropetrovs'k: Vydavnytstvo DUEP.

Prezydent Ukrainy. (2002). Ukaz "Pro Natsional'nu doktrynu rozvytku suspil'stva" № 347 vid 17 kvitnia 2002 roku.

Rogova, G. V. (1974). O principah obuchenija inostrannym jazykam. Inostrannye jazyki v shkole, 6, 85-95.

Solovova, E. N. (2002). Metodika obuchenija inostrannym jazykam : bazovyj kurs lekcij. Moskva: Prosveshhenie.

Stronin, M. F. (1981). Obuchajushhie igry na uroke anglijskogo jazyka (iz opyta raboty) : posobie dlja uchitelja. Moskva: Prosveshhenie.

Ter-Minasova, S. G. (2000). Jazyk i mezhkul'turnaja kommunikacija. Moskva : Slovo / Slovo.

Huhareva, E. K. (2009). Rol' delovoj igry v obuchenii sotrudnikov sovremennoj kampanii. Innovacii v obrazovanii, 10, 85-96.

Chubarova, L. A. (2003). Individualizacija problemnyh situacij v uchebnom processe vuza (na materiale izuchenija nemeckogo jazyka na jazykovom fakul'tete) (Kandidatskaja dissertacija). Tjumenskij gosudarstvennyj universitet, Tjumen', Rossijskaja Federacija.

Scherban', P. M. (2004). Navchal'no-pedahohichni ihry u vyschykh navchal'nykh zakladakh. Kyiv: Vyscha shkola.

Jel'konin, D. B. (1978). Psihologija igry. Moskva: Pedagogika.

Yavors'ka, Zh. (2005). Dilovi ihry ta ikh rol' u pidhotovtsi suchasnykh fakhivtsiv. Visnyk L'vivs'koho Universytetu, 19, 241-246.

Eitington, J. E. (2001). The winning trainer : winning ways to involve people in learning. Oxford: Butterworth-Heinemann.

Livingstone, C. (1988). Role Play in Language Learning. Moskva: Vysshaia shkola.

Philips, B. D. (1994). Role-playing games in the English as a Foreign Language Classroom. Crane Publishing Ltd.

Reeves, N. \& Wright, C. (1996). Linguistic auditing: a guide to identifying foreign language communication needs in corporations. Clevedon : Multilingual Matters.

Richards, J. C., Rodgers, T. S. (2001). Approaches and methods in language teaching. Cambridge: Cambridge University Press. 